\section{No nuclear doubts for Japan}

Tokyo

By 2030, Japan will have more than 120 nuclear power reactors supplying over half the country's electricity needs. Fastbreeder reactors will be on line, and fuel cycle facilities will provide a large proportion of the nuclear industry's enriched uranium requirements, reprocess most of its spent fuel and store all its waste. Such is the "vision" of Japan's nuclear industry outlined in a report recently submitted to the Ministry of International Trade and Industry by the nuclear subcommittee of the Advisory Committee of Energy. But where will all these nuclear plants be located and will the Japanese public willingly accept them?

Japan has 32 reactors generating nearly 25 million kilowatts, putting Japan behind the United States, the Soviet Union and France in total nuclear capacity. Twentysix per cent of Japan's electricity is nuclear generated.

According to the report, nuclear power capacity will more than double to 62 million kilowatts by the end of this century and, assuming a growth in Gross National Product of 2.5 per cent, rise to 137 million kilowatts by 2030 to provide 58 per cent of Japan's needs. This will require the construction of 116 new reactors at the rate of 2 or 3 a year. Ten new reactors are under construction and seven more are planned.

Two areas in Fukui and Fukushima prefectures contain most of the nation's nuclear plants. Their presence has brought economic benefits but there is resistance to further expansion. The town of Ohi in Fukui Prefecture, for example, has earned more than Y11,000 ( $£ 47$ million) in fixed property revenue funds, grants from the central and local government and redemption taxes during the past 15 years. But plans to double the number of reactors in the town to four have led to mass demonstrations; in 19841,400 riot police had to be mobilized to contain thousands of demonstrators protesting outside public hearings in the town.

The subcommittee's report makes several recommendations to promote public understanding of nuclear power so that expansion can proceed "smoothly". Safety should be strictly maintained in the plants to ensure the public's understanding of the "safety" of nuclear power. Nuclear power technology should be explained in simple, easy-to-understand terms, and the central and local government should positively promote nuclear power in school education.

Japan certainly has an enviable safety record, with far fewer shutdowns due to accidents than for example, the United States. But accidents do occur, such as the leak of low-level radioactive waste at the
Tsuruga power plant in 1981 and the exposure of an official of the International Atomic Energy Agency to traces of plutonium earlier this year.

A key element in future plans is the construction of a huge fuel cycle facility for uranium enrichment, fuel reprocessing and low-level waste storage in Aomori Prefecture at a cost of one million million yen ( $£ 4,300$ million). But this facility, for which approval was granted by the prefectural government in 1985, has yet to gain the unanimous approval of the local fishing cooperative and the start of construction has been delayed.

Fishing cooperatives wield considerable political power in Japan as do other blocks of rural voters who traditionally support the ruling party. Promises of Y177,000 million yen ( $£ 750$ million) in contracts for local companies and 1,400 jobs have won approval for the project from other sections of the local community. schedule in the $1990 \mathrm{~s}$, it will provide 30 per cent of Japan's enriched uranium requirements by the year 2000 , and will be capable of reprocessing most of the spent
If the Aomori complex is completed on fuel that is now sent to French and British facilities. According to the report, a second fuel reprocessing plant will be built in Japan in 2010 to meet increased demand.

Low-level radioactive waste will be stored at Aomori in a plant with an eventual capacity of 3 million 200-litre drums. It will be capable of dealing with all Japan's low-level waste produced by 2030 and beyond.

Greatest growth over the next 45 years is seen in establishing the fuel cycle. Expenditure is expected to amount to Y70,000 million million yen $(£ 300,000$ million) by 2030 . The only note of restraint in this bullish assessment of the future of Japan's nuclear industry is in regard to fast-breeder reactors, commercial operations of which are predicted to start in 2020 , ten years later than expected.

But a big question mark hangs over the locations of the proposed new plants. The report calls for the establishment of 20 new sites without clearly stating where they will be. Development of new siting technology is advocated so that nuclear plants can be placed underground, on the sea, and close to population centres. Clearly Chernobyl has not shaken the confidence of Japan's nuclear power planners.
David Swinbanks

\section{Chernobyl}

\section{Experimental speculations}

THE Soviet Politburo, apparently re- $\mid$ would by then amount to some 4 per cent sponding to a torrent of questions about the mysterious "unauthorized experiment" said to have been under way when the Chernobyl reactor accident occurred on 26 April, said last week that the power station crew was attempting to operate the reactor at a low power, below that for which it was designed.

From the beginning, Soviet statements have said that the Chernobyl reactor was operating at 7 per cent of full power at the time of the accident. Many reactor engineers in the West now consider that the most likely explanation of the Soviet statement is that those concerned were trying out some scheme for operating the reactor's housekeeping functions from the station turbine proper, and not from the stand-by diesel sets provided to guard against disconnection from the Soviet electricity grid.

While operating at full power, reactors are naturally able to deal with this "hotel" load from their own production of electricity, but the removal of fission product heat from a shutdown reactor requires an external source of power. Measurements of fallout from Chernobyl suggest that the reactor had been shut down for some hours before the first release of radioactivity began, which would suggest that the decay heat of the fission products of the total power, less than the 7 per cent quoted by Soviet sources.

Dr David Hicks, director of the UK Atomic Energy Authority's water reactor programme (chiefly concerned with the safety of pressurized water reactors) said earlier this week that such an operation. well outside the power range for which the Soviet RBMK reactors are designed, could well have made the Soviet reactor prone to the instabilities for which it is known, especially because a core which had been in use for 1.5 years would have accumulated such a load of fission products that the production of even a few per cent of full power by fission would have required that the control rods should be to a large extent withdrawn.

The occurrence of steam voids within the cooling system would, in these conditions, have created power excursions which it might have been difficult to control by means of the control rods, which move in narrow water channels where their free fall is impeded. Hicks emphasized, however, that his theory of what may have happened is only one of many.

Much of what is known of the Soviet reactors derives from three consultations in the mid-1970s when British and Soviet designers exchanged information about the RBMK and its British analogue. 